\title{
Using mobile devices to leverage student access to collaboratively-generated re- sources: A case of WhatsApp instant mes- saging at a South African University
}

\author{
Patient Rambe ${ }^{1}$ Crispen Chipunza ${ }^{2}$ \\ ${ }^{1}$ University of the Free State, South Africa \\ ${ }^{2}$ Central University of Technology, South Africa
}

\begin{abstract}
WhatsApp instant messaging has potential to bridge information divides between educators and students. Its capacity to create personalised environments was harnessed to share collectively generated educational resources among previously disadvantaged students (PDS) students at a South African university. Data analysis combined mobile instant messagingmediated (WhatsApp) interactions among students and educators and student evaluations of WhatsApp's value using blogs. Results suggest that students conceived WhatsApp as a lever for bridging access to peer-generated resources, heightening on-task behaviour and promoting meaningful context-free learning.
\end{abstract}

Keywords: WhatsApp, MIM, collectively-generated resources, dialogic interactions

\section{Introduction}

The uptake of mobile phones by the South African population especially university students has been impressive over the past years (Benjamin, 2011). This uptake suggests the potential of mobile gadgets to steer productive academic engagement in networked learning communities. Surprisingly, empirical evidence on meaningful academic appropriation of cell phones, especially mobile instant messaging (MIM) remains disappointingly low.

Few studies (Ng'ambi and Hardman, 2004; Rambe and Bere, 2012) that report on the adoption of MIM for learning at South African universities do not necessarily target previously disadvantaged off campus students or users of WhatsApp who reside in geographically dispersed locations. Previously disadvantaged students (PDS) are learners from historically underprivileged backgrounds who attended impoverished high schools that have limited ICT backgrounds (Rambe, 2012). They often display varying degrees of preparedness for university and exhibit different competencies (HodgkinsonWilliams and Ng'ambi, 2009).

Mindful of the need to promote meaningful student academic participation and closing the articulation gap in South African higher educational institutions (Fisher and Scott, 2011; Hendricks and Volbrecht, 2003; Rambe, 2009; Scott, 2007), the ex- 
ploitation of the affordances of ubiquitous technology accessible to PDS students for improving their academic engagement cannot be over-emphasised.

\section{MIM for meaningful learning at South African universities}

MIM involves the transmission of textbased messages between conversing interactants. Researchers in South Africa have studied MIM among students mediated by lecturers' appropriation of an anonymous MIM service, Dynamic Frequently Asked Questions (DFAQ) for academic purposes (Hodgkinson-Williams and Ng'ambi, 2009); the potential of WhatsApp to support collaborative problem solving of IT problems (Rambe and Bere, 2012) and the use of Mxit, a popular South African MIM service, for collaborative discussions (Makoe, 2010). Overall, these studies point at the capacity of MIM to foster knowledge sharing, enhance peer-based support on educational matters and nurture knowledge communities.

\section{Conceptualising access to educa- tional technologies in resource poor environments}

A historical tradition of conceptualising access emphasises access to and ownership of technologies like computers and internet networks (Castells, 2002; Van Dijk and Hacker, 2003). The absence of or lack of access to these technologies is considered by these scholars as the "digital divide." Variation within countries and between individuals' access to the Internet, other important ICTs (e.g., mobile phones) are also highly relevant to digital divide issues (Vehovar, Sicher, Husing and Dolnicar, 2006). In reference to resourced poor environments, Van Dijk (1999) captures the multifaceted conception of access by alluding to issues such as lack of interest, computer anxiety, non-possession of computers, lack of digital skills caused by inadequate education or social support ("skills access") and lack of significant usage opportunities ("usage access").

For Africa, the concept of 'access' signals a recognition of universal access to computers, albeit a limited focus on the subtleties of intra-class and intra-cultural variations in access.

\section{Theoretical Framework}

The study is based Sen's Capabilities Approach. Capabilities denote "a person's freedom to lead one type of life or another $[\ldots]$ to choose from possible livings" [Sen, 1992, p. 40] and is based on functionings and freedoms (Alkire, 2005, p. 121). Functionings denote the various things a person may value doing or being", (Sen, 1999, p. 75). Freedom emphasises " the real opportunity that we have to accomplish what we value"' (Sen,1992, p. 31). 'Positive' freedom describes individual choices about possible actions and achievements, while the 'negative' view of freedom underpins the absence of a class of restraints that one person may exercise over another. Sen's (1987) pursuit of freedom is implicated in the pursuit of power in decision making. Consequently, conditions of deprivation and exclusion that constrain student accessibility to peer-based social networks for organised academic activities are instantiations of restrained academic power or retrained freedom conceptually.

\section{Research questions}

1. How does student possession of WhatsApp enabled phones enhance (or disrupt) their agency (access and productive use) over collectively generated educational resources? 
2. How does access (/ lack of access) shape their capabilities as engaging learners in online communities?

3. What other emergent forms of the digital divide are implicated in student appropriation of mobile phones for academic engagement?

\section{Research Methodology}

Data was collected from fourth year human resource management students enrolled for a Research Methodology module $(n=72)$. To boost student engagement with collectively generated academic resources,students were encouraged to interact anonymously among themselves, with the lecturer, and the online facilitator (i.e. a guest online lecturer) using their cell phone numbers. Anonymous interaction was envisaged to protect the identities of shy, low self-esteem PDS who often struggled to publicly express their views in lectures. Using the inductive data analysis (Delport and De Vos, 2011) the themes related to differential uses of WhatsApp that emerged from student blog postings and WhatsApp-mediated lecturer-student and lecturer-peer interaction were put into conversation with Sen's conceptualisation of functionings and freedom as demonstrated below (see Table 1).

\section{Findings}

WhatsApp usage enabled students to share information on various issues pertaining to the course. Conversations between and among students using WhatsApp demonstrate the sharing of academic information. Informal information sharing is evident in their conversations as illustrated below:

+27786672737: " Do we have to do data analysis of it as we have never done it in class'
+27833018066: 'Yes, we must do data analysis maybe you were not in class Dr Chipunza did it"

Excerpts suggest that students transcended the information sharing role by assuming academic 'advisory' roles to their peers via WhatsApp:

+27837204321: My advice will [...] ensure that you investigate literature in line with your research topic [...] you can use existing literature and be able to expand your findings $[\ldots]$.

With WhatsApp, lecturer's capabilities manifested in his intentional modeling of learning tasks through critical questioning:

Lecturer: What is the difference between concepts and constructs in research?

In addition to its enhancement of intentional design of learning tasks, WhatsApp application also served as an information gateway for linking students to other ICT applications like Blackboard and deepening their knowledge of their interfaces.

+27833137927: Hi guys how do I open the test page [...] where do $\mathrm{i}$ click to get it?

WhatsApp application also provided students with the freedom to accomplish the academic commitments they value after hours. For instance, off campus students with limited access to library internet connectivity 
Table 1: An analytical framework of original Whats App and Blog posts using Sen's Capabilities Approach

\begin{tabular}{|c|c|c|c|}
\hline $\begin{array}{l}\text { Capabilities } \\
\text { Approach/Theory }\end{array}$ & Themes & $\begin{array}{l}\text { Original Artifacts: } \\
\text { WhatsApp / Blogs }\end{array}$ & Research Comments \\
\hline Functioning & $\begin{array}{l}\text { Academic } \\
\text { Networking }\end{array}$ & $\begin{array}{l}\text { I enjoy using it as a communication } \\
\text { tool. It helps with the Research } \\
\text { Methodology in the sense that the } \\
\text { questions being asked and answered, } \\
\text { we all share it as groups [student } \\
\text { blog postings ] }\end{array}$ & $\begin{array}{l}\text { Whats App is de- } \\
\text { ployed as a commu- } \\
\text { nication, transactional } \\
\text { platform }\end{array}$ \\
\hline Capabilities & $\begin{array}{l}\text { Collaborative } \\
\text { Engagement }\end{array}$ & $\begin{array}{l}\text { My advice wil pls ensure dat u in- } \\
\text { vestigate acrding to ur research topic } \\
\text { en ur literature review in terms of } \\
\text { guidance dat Dr Chris uploaded in } \\
\text { ethutho-ur topic will guide of what } \\
\text { need to be done [...] [students advice } \\
\text { on Whats App] }\end{array}$ & $\begin{array}{l}\text { Student advise a peer } \\
\text { on how to develop a } \\
\text { credible literature } \\
\text { review }\end{array}$ \\
\hline Freedom & $\begin{array}{l}\text { Positive } \\
\text { Freedom } \\
\text { Negative } \\
\text { Freedom }\end{array}$ & $\begin{array}{l}\text { Whats App [...] helps us as student to } \\
\text { assist each other with the difficulties } \\
\text { we come across in the course. It has } \\
\text { been very useful for me as a student } \\
\text { working in Kimberley as due to the } \\
\text { distance between Kim and Bloem I } \\
\text { unfortunately fail to attend most } \\
\text { classes and whatzup helps me to } \\
\text { catch up [student reflection on a per- } \\
\text { sonal blog] } \\
\text { There is no internet access. Can } \\
\text { those in offices make copies for us if } \\
\text { they log on earlier please [student } \\
\text { posting on WhatsApp] }\end{array}$ & $\begin{array}{l}\text { Whats App supports } \\
\text { knowledge sharing. It } \\
\text { also bridges the phys- } \\
\text { ical and information } \\
\text { divide between stu- } \\
\text { dents } \\
\text { Hard copies are con- } \\
\text { ceived as comple- } \\
\text { ments to online ac- } \\
\text { cess due to erratic } \\
\text { networks. }\end{array}$ \\
\hline
\end{tabular}

and those who experienced power cuts in their residences resorted to WhatsApp generated resources to sustain their access to information during these times.

The lecturer also employed WhatsApp for academic planning and scheduling of tasks like what the students had to prepare for in the next lecture

Lecturer: Dear student. Remember tomorrow Tuesday (7 August) your group is presenting [...] put your presentation on power point [...] rratic institutional networks such as Blackboard:

+27836186908: Dr, this test switches off on its own [...] after 19 minutes, it submits automatically even though one has not yet saved.

Blogs comments also showed that students felt that WhatsApp gave them the opportunity to express themselves freely in a non-restricted environment thus removing the low participation constraints characteristic of lectures. 


\section{Discusion}

The WhatsApp platform created an ambient, informal "rendezvous" [Rambe and $\mathrm{Ng}$ 'ambi, in press] for student expression of their choices about information sources and academic resources preferred and available for sharing (Voogt, Knezek, Cox, Knezek and Brummelhuis, 2011). The sharing of information through WhatsApp peer groups enabled the development of complex hierarchy of individual roles among students such as knowledge brokers, knowledge seekers and givers and informal mentors. As such, WhatsApp can be interpreted as a platform that broadened and leveraged students' capacities like collaborative engagement and meaningful appropriation of educational resources.

WhatsApp, to some extent, managed to redress some information asymmetries that are often found among students from poor backgrounds. Off campus students' freedom to access to WhatsApp-enabled phones meant that they could access academic content anytime, anywhere unhindered by location.

Our results showed that WhatsApp created a viable technological context for role play in problem solving and advising peers on complex academic matters; increased access to educational resources regardless of distance; created a quasiinformal learning context that students could use for self-discovery and intuitive learning (Webb, 2011).

Lecturer's modelling of academic tasks resulted in students developing transformative technological skills which enabled them to explore the interface of WhatsApp with other technologies within the institution such as the Blackboard (Rambe and Bere, 2012).
Our study exposed the occasional challenges of internet connectivity for the expression of student functionings (e.g. academic networking) due to power cuts or erratic networks and limited access to educational materials via institutional networks after hours. This was indicative of the capacity of WhatsApp to expose the constraints of negative freedom such as the "networked divide." This divide describes the connected network polarity between those who are continually connected and those who experience variations in connectivity across different spaces (Wolff and MacKinnon, 2002).

Our study demonstrated that on campus, all students enjoyed positive freedom manifested through relatively equal access to networks notwithstanding variations in networked access beyond campus after hours. These findings resonate with Mutula (2008) who observes that technological binaries in conceptualising the digital divide fail to address issues of use and quality of access that have become pertinent in an increasingly interconnected world.

\section{Implications for pedagogy}

Our study demonstrates that studentcentred constructivist ways of generating knowledge via ubiquitous technologies are critical to student effective engagement with peers and educators. Online facilitation should therefore embrace more than question-based consultation to include assisting students in the development of academic applications that support research such as referencing software and meta learning skills.

Students' access to mobile learning networks was sometimes disrupted by unreliability of networks that limited effective access to learning resources via WhatsApp. This erratic nature of the mo- 
bile networks necessitates the provision of wireless hotspots on campus to support universal access on campus.

\section{Conclusion}

This study investigated the potential of a MIM service, WhatsApp, to support student access and appropriation of collectively generated educational resources. The study findings provide evidence on this MIM's capacity to heighten student access to learning resources through collaborative dialogue and engagement between dyads and collectives. The Capabilities framework, which collectively examines technology users' capabilities, functionings and their positive and negative freedoms, was drawn upon to provide a unified interpretive and analytical framework for interpreting access in resource-poor environments. Overall, WhatsApp served as a tool for bridging access to learning resources, rendering peer-based and hierarchical support, leveraging on-task behaviour and enhancing meaningful context-free learning. Several access impediments like student limited access to Web-enabled smart phones and erratic network connectivity were reported. Any interventions aimed at redressing these access issues should focus on: briding asymmetries in access to learning materials through timeous context free delivery of pedagogy, optimising mobile affordances by closing the black holes in connectivity and the broadening the social contexts of applications of these social technologies by interfacing mobile technologies with other complementary web-based technologies.

\section{References}

[1]Alkire, S. (2005). Why the Capability Approach? Journal of $\mathrm{Hu}$ man Development 6(1), 115-133.
[2] Benjamin, C. "SA 'Leads Way' in Mobile Marketing," Business Day, 14 February 2011, p. 4, available at

http://www.businessday.co.za/arti cles/ Content.aspx ?id=134236 (accessed 20 March 2012).

[3] Castells, M., 2002. The Internet Galaxy. Oxford University Press, Oxford.

[4] Delport, C and De Vos, A. (2011). Professional research and professional practice. In A. DeVo, H., Strydom, C. Fouche' and C. Delport. (Eds). Research at grassroots: For the social and human service professions (pp. 45-60). Van Schaik Publishers: Pretoria

[5] Fisher, G and Scott, I (2011). Closing the skills and technology gap in South Africa Background paper 3: The role of higher education in closing the skills gap in South Africa. The World Bank Human Development Group, Africa Region October 2011.

[6] Hendricks, N. and Volbrecht, T. (2003). RPL as cognitive praxis in linking higher education, the African Renaissance and lifelong learning, South African Journal of Higher Education: 200317 (1): 47-53)

[7] Hodgkinson-Williams, $\mathrm{C}$ and Ng'ambi, D. (2009). Case Study 5: Mobile learning, Centre for Educational Technology, University of Cape Town.

[8] Makoe, M. (2010): Exploring the use of MXit: a cell-phone social network to facilitate learning in distance education, Open Learning: The Journal of Open, Distance and e-Learning, 25:3, 251257

[9] Mutula, S. (2008). Digital divide and economic development: case 
study of sub-Saharan Africa. The

Electronic Library, 26(4), 468-489.

[10] Ngambi, D. and Hardman, J (2004). Towards a knowledgesharing scaffolding environment based on learners' questions. British Journal of Educational Technology, 35(2), 1-10.

[11] Rambe, P. (2009). The impact of social networking sites on academic relations and student learning, PhD Thesis, University of Cape Town.

[12] Rambe, P. and Bere, A. (2012). An M-Learning Strategy for leveraging learner participation: Using WhatsApp Mobile messaging at a South African University of Technology, Paper presented at Southern African Computer Science Lecturers' Association Conference (SACLA) (pp. 29-36), Black Mountain Leisure \& Conference Hotel, Thaba 'Nchu, outside Bloemfontein, 1-3 July 2012.

[13] Rambe, P and Ng'ambi, D. (In Press). Learning with and from Facebook - uncovering power asymmetries in educational interactions. Australasian Journal of Educational Technology

[14] Scott, I. (2007). Educational strategies for improving graduate output. A Case for Improving Teaching and Learning in South African Higher Education. Higher Education Monitor No. 6 www.che.ac.za/documents/.../17HE_Monitor_6_ITLS_Oct2007.p df

[15] Sen, A. (1987). The Standard of Living, edited by Geoffrey Hawthorn. Cambridge: Cambridge University Press

[16] Sen, A. (1992). Inequality Reexamined. New York and Cambridge, MA: Russell Sage and Harvard University Press.
[17] Sen, A. K. (1999). Development as freedom. New York: Anchor Books.

[18] van Dijk, Jan. (1999). The Network Society, Social aspects of the new media. London, Thousand Oaks, New Delhi: Sage Publications

[19] Van Dijk, J., Hacker, K., 2003. The digital divide as a complex, dynamic phenomenon. The Information Society 19 (4), 315-326.

[20] Vehovar, V., Sicherl, P., Hüsing, T., i Dolnicar, V. (2006). Methodological challenges of digital divide measurements. The Information Society, 22(5), 279-290.

[21] Voogt, J., Knezek, G., Cox, M., Knezek, D \& Brummelhuis, A. (2011). Under which conditions does ICT have a positive effect on teaching and learning? A Call to Action. Journal of Computer Assisted Learning, 1-11.

[22] Webb, M. (2011). Changing models for researching pedagogy with information and communications technologies, Journal of Computer Assisted Learning, 1-15

[50] Wolff, L and MacKinnon, S. What is the digital divide. TechKnowLogia, July - September 2002 @ Knowledge Enterprise, Inc 